\title{
GEOPHYSICAL AND WELL CORELLATION ANALYSIS OF OGO FIELD: A CASE STUDY IN NIGER DELTA BASIN OF NIGERIA
}

\author{
M. O. Ehigiator ${ }^{1,}{ }^{*}$ and N. C. Chigbata ${ }^{2}$ \\ 1. Department of Physics, Benson- Idahosa University, Benin, Benin City, Edo State. NigERia. \\ 2, No. 12, FunMILAYO ONARONKE STREET, AKOKA, YABA, LAGOS. LAGOS STATE. NIGERIA \\ E-mail addresses: ${ }^{1}$ mehigiator@biu.edu.ng, ${ }^{2}$ nnake2@gmail.com
}

\begin{abstract}
A suite of geophysical wire line logs were run in hole. The wells data were acquired from bottom to top and not top to bottom. Basically, we have the qualitative and the quantitative evaluation techniques.Qualitative means is usually used for identification of the type of lithology and also for the component of the formation. Quantitative is used to estimate numerically, the value of what is in the formation. The logs used for evaluation were: Spontaneous potential logs and the Gamma ray logs. These were used to determine the lithology of the formation. Resistivity logs were run in hole to also determine the water saturation in the formation. The Formation Density and the compensated Neutron logs were run in hole to differentiate the gaseous zone from the oil zone in the Hydrocarbon Formation Ogo1, Ogo2 and Ogo3 from well correlation depicts that the subsurface stratigraphy is that of sand - shale intercalations. Two prominent hydrocarbon bearing reservoirs (R1and R2), at Depth $1563 \mathrm{~m}$ and $1642 \mathrm{~mm}$ respectively were identified. The reservoirs were found to have average porosity of 0.22 , water saturation 0.43 and Hydrocarbon saturation of 0.57 . The reservoirs have permeability of $1376 \mathrm{~m}$, volume of oil in place for reservoir 1 and 2 is $39900 \mathrm{~m}^{3}$ and $9647 \mathrm{~m}^{3}$ respectively. More. Well correlations are recommended for proper drilling and well completions. $4 D$ seismic acquisitions should be encouraged for proper view of the formation.
\end{abstract}

Keywords: Formation, Water Saturation, Hydrocarbon, Reservoir Porosity

\section{INTRODUCTION}

In a country such as Nigeria, where hydrocarbon has been the mainstay of her economy, it is observed that for decades of Hydrocarbon Exploration and Exploitation, attention has been on structural traps and currently most of the identified structural closures on the shelf and upper slope have been drilled and the search for hydrocarbon is becoming increasingly more difficult and expensive [11].

The earth is heterogeneous in nature with vary components of rocks which differ in texture and and chemical components. For the scope of this research, The Sandstone being prevalent in the Niger Delta was studied. The sandstone is porous and permeable. This permeability property brings about the interconnection of the pores. This interconnection of the pores contributes to the prolific nature of the rocks which enhances the storage of fluid and hence a good reservoir rock.

\subsection{The Location and Geology of the Area}

The oil field is called the OSSU or OMI 124. It is located in the Oguta community of Imo state. It is an onshore field

* Corresponding author, tel: + 234-803-381-9640 located within latitude $5030 \mathrm{~N}$ and longitude $6^{0} 00 \mathrm{E}$ to latitude $5^{0} 40 \mathrm{~N}$ and longitude $6^{0} 20 \mathrm{E}$ in the Niger Delta. The oil field is owned by Addax Petroleum Development Nigeria. The types of formation associated with this area which are not different from the tropical Niger Delta formation are the Benin, Agbada and Akata formations $[4,17]$.

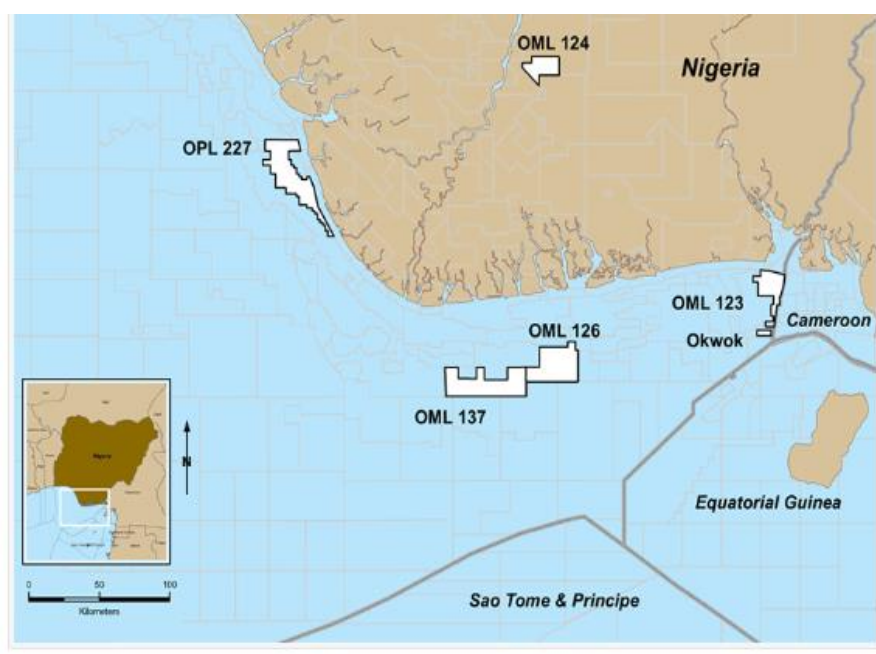

Figure1: Map showing location of the well 


\subsection{Aims and Objectives}

The aims and objectives of this research are:

1. To identify the productive zones of hydrocarbon.

2. To define the petrophysical parameters like porosity, permeability, and hydrocarbon saturation and lithology of zones.

3. To determine depth, thickness.

\section{DETERMINATION OF POROSITY}

The porosity $\phi$ of a Formation can be obtained from the Bulk density if the mean density of the rock matrix and that of the fluids it contains are known [5]. The bulk density $\boldsymbol{\rho}_{\boldsymbol{b}}$ of a formation can be written as a linear contribution of the density of the rock matrix $\rho_{m a}$ and the fluid density $\rho_{f}$ with it present in proportions (1- $\left.\Phi\right)$ and $\Phi$, respectively:

$$
\rho_{b} \emptyset=(1-\phi) \rho_{m a}+\phi \rho_{f}
$$

When solved for porosity, we get

$$
\varnothing=\frac{\rho_{\mathrm{ma}}-\rho_{\mathrm{b}}}{\rho_{\mathrm{ma}}-\rho_{\mathrm{fl}}}
$$

In (1) and (2), $\boldsymbol{\rho}_{\boldsymbol{b}}$ is the bulk density of the Formation, $\boldsymbol{\rho}_{\boldsymbol{m} \boldsymbol{a}}$ is the density of the rock matrix, $\boldsymbol{\rho}_{\boldsymbol{f l}}$ is the density of the fluids occupying the porosity and $\Phi$ is the porosity of the rock. Common values of matrix density (in $\mathrm{g} / \mathrm{cm}^{3}$ ) are: Quartz sand - 2.65, Limestone - 2.71 and Dolomite 2.87

\subsection{Determination of Shale Content}

In most reservoirs the lithologies are quite simple, being cycles of sandstones and shales or carbonates and shales. Once the main lithologies have been identified, the gamma ray log values can be used to calculate the shale volume $\boldsymbol{V}_{\boldsymbol{s} \boldsymbol{p}}$ of the rock. This is important as a threshold value of shale volume is often used to help discriminate between reservoir and non-reservoir rock. Shale volume is calculated in the following way: First the gamma ray index $\mathrm{I}_{\mathrm{GR}}$ is calculated from the gamma ray log data using the relationship [3].

Where

$$
I_{G R}=\frac{G R_{\log }-G R_{\min }}{G R_{\max }-G R_{\min }}
$$

$\mathrm{I}_{\mathrm{GR}}$ is the gamma ray index, $\mathrm{GR}_{\log }$ is the gamma ray reading at the depth of interest, $\mathrm{GR}_{\text {min }}$ is the minimum gamma ray reading. (Usually the mean minimum through a clean sandstone or carbonate formation)

$\mathrm{GR}_{\max }$ is the maximum gamma ray reading. (Usually the mean maximum through a shale or clay formation))

$$
V_{s h}=0.83\left(2^{\left(2.7 \times I_{G R}\right)}\right.
$$

\subsection{Water Saturation Estimation}

Water saturation can be expressed as a function using Archie's method

$$
S_{w}=\left(\frac{R_{w}}{R_{t}}\right)^{\frac{1}{n}}
$$

In (5), $S_{w}$ is the Formation water saturation, $R_{w}$ is the Formation water resistivity $(\Omega \mathrm{m}), \mathrm{R}_{\mathrm{t}}$ is the True formation resistivity $(\Omega \mathrm{m})$ and $\mathrm{n}$ is the saturation exponent. This is the basic equation to calculate water saturation. It can be used for all lithologies, but primary it is made for clean porous rocks

Saturation exponent (n) defines density of the fluid. Its saturation lines were empirically derived using electrical properties of the water/oil interface and wettability of the matrix can be established from the well logs or cores; usually taken as (1.8-2.2). Lower value of $n$ leads to more optimistic lower water saturation calculations [8].

\subsection{Hydrocarbon Estimation}

To calculate for volume of oil in place or hydrocarbon pore volume (HCPV) we use the equation:

$$
V O O I P=A H\left(1-S_{W}\right) \emptyset
$$

Here, $\mathrm{A}$ is the cross-sectional area, $\mathrm{H}$ is the thickness, $\mathrm{Sw}$ is the water saturation and $\varnothing$ is the porosity. For the purpose of this study the area was estimated using isopach maps. For reservoir $1\left(25000 \mathrm{~m}^{2}\right)$ was the area used while for reservoir $2\left(17000 \mathrm{~m}^{2}\right)$ was used.

\subsection{Permeability}

In this study we use the Asquith and Krygoskwi method of 2004 [2] stated as:

$$
K=\left(\frac{250 \times \emptyset^{3}}{s_{\text {wirr }}}\right)^{2}
$$

Here $\mathrm{K}$ is the permeability, $\emptyset$ is the porosity and $s_{\text {wirr }}$ is the irreducible water saturation.

\section{ANALYSIS OF RESERVOIRS}

Table 1 shows the results of some computed petrophysical parameters for reservoir 1 which cuts across Ogo well 1 and 2 . The reservoirs were penetrated at 1557-1574 meters for Ogo 1and from 1569-1575 meter in Ogo 2. It has a gross thickness ranging from 617 meters and a net thickness ranging from 4-10 meters, the net /gross thickness (N/G) ranges 0.59-0.66. Reservoir 1 has an average porosity value ranging from 0.19 to 0.24 . The water and hydrocarbon saturation have average values of 0.33 or $33 \%$ and 0.67 or $67 \%$ respectively.

The porosity values for reservoir 1 show good ratings. The permeability values obtained from reservoir 1 are fair and will permit the flow of fluid within the reservoir. The hydrocarbon saturation shows a high proportion of hydrocarbon to the quantity of water. We can say that reservoir 1 is a hydrocarbon saturated reservoir.

Table 2 shows the result of some computed petrophysical parameters for reservoir 2 which cuts 
across Ogo well 1,2 and 3. The reservoirs were penetrated at 1641-1649 meters for Ogo 1, from 16381644 meters in Ogo 2 and 1647-1665 meters in Ogo3. It has a gross thickness ranging from $6-18 \mathrm{~m}$ and a net thickness ranging from $4-11 \mathrm{~m}$, the net /gross thickness $(\mathrm{N} / \mathrm{G})$ average of 0.64 . Reservoir 2 has an average porosity value ranging from 0.13 to 0.29 . The water and hydrocarbon saturation have average values of 0.53 or $53 \%$ and 0.47 or $47 \%$ respectively. The saturation of water is slightly higher than that of the hydrocarbon.

From Table 3 reservoir 1 has an average porosity of 0.26 compared to the 0.17 porosity in reservoir 2. The hydrocarbon saturation in reservoir 1 is 0.67 while that of reservoir 2 is 0.47 . This means that reservoir 1 contains more hydrocarbon than reservoir 2. The permeability of both reservoirs are very good. Although reservoir 2 contains more water but there is still a good amount of hydrocarbon. The irreducible water saturation $\mathrm{S}_{\text {wirr }}$ show good ratings. In reservoir 1 it is 0.10 and 0.1 in reservoir 2. From interpretations the two reservoirs show high hydrocarbon potentials.

\subsection{Reservoir Classification}

In table 1.3 are the summary of the average results of the important petrophysical parameters utilized as variables that determine reservoir quality. These parameters are subjected to statistical analyses by considering their values across all delineated reservoirs in the three wells of the study area. From this analysis we can say that reservoir 1 is the most prolific in the Ossu field while reservoir 2 is least prolific.

\section{RESULTS AND DISCUSSION}

For the log interpretation shown in figure 2 below, the correlation of the well helps improve the knowledge of the formation of the study field. Three lithologies were identified using the gamma ray log and shale and sand. From the lithology the interval coloured black is shale while the interval coloured grey is sand.

Two sand bodies were mapped called R1, R2, and correlated across the field. The results obtained from this study are based on both petrophysical analysis and well log interpretation. The well correlation panel showing the tops and bases of the reservoirs is shown in figure 2 below. Figure 2 shows three reservoirs Ogo1 Ogo2 and Ogo3. R1 and R2 occur at depth $(1557 \mathrm{~m})$ and $(1641 \mathrm{~m})$ respectively in Ogo 1 while in Ogo 2 it occurs at (1569 m) and $(1638 \mathrm{~m})$ respectively. R2 for Ogo 3 has its depth at (1647 m).

The analysis of all the well section revealed that each of the sand unit extend through the field and varies in thickness with some unit occurring at greater depth than their adjacent unit in other words there is possible evidence of faulting. The shale layers were observed to increase with depth along with a corresponding decrease in sand layers. In Niger Delta this indicates a transition from Benin to Agbada formation. From the analysis the two reservoirs were identified as hydrocarbon bearing reservoirs across 0go1, 2, and 3, with the exception of Ogo2 in reservoir 2.

\subsection{Conclusion}

Spontaneous Potential, Gamma ray, resistivity, Neutron and density logs were employed in the analysis and examination of an oil field in western Niger Delta. Three wells 0go1, Ogo2 and Ogo3 were considered. Correlation of these wells indicates that there is interbedding in the subsurface stratigraphy.

Table 1: Summary of Petrophysical Parameters Obtained for Reservoir 1

\begin{tabular}{|c|c|c|c|c|c|c|c|c|c|c|c|c|}
\hline Wells & $\begin{array}{l}\text { Top } \\
\text { (m) }\end{array}$ & $\begin{array}{l}\text { Bottom } \\
\text { (m) }\end{array}$ & $\begin{array}{c}\text { Gross } \\
\text { Thickness } \\
\text { (m) }\end{array}$ & $\begin{array}{c}\text { Net } \\
\text { Thickness } \\
\text { (m) }\end{array}$ & $\begin{array}{l}N / G \\
(\%)\end{array}$ & $\begin{array}{l}\text { Porosity } \\
\varnothing(\mathrm{v} / \mathrm{V})\end{array}$ & $S_{\text {wirr }}$ & $\begin{array}{c}\text { Water } \\
\text { Saturation } \\
\mathrm{S}_{\mathrm{w}} \\
\end{array}$ & $\mathrm{S}_{\mathrm{h}}$ & $V_{\text {sh }}$ & $\begin{array}{c}\mathrm{K} \\
(\mathrm{mD})\end{array}$ & $\begin{array}{l}\text { Vooip } \\
\left(\mathrm{m}^{3}\right)\end{array}$ \\
\hline Ogo1 & 1557 & & 17 & 10 & 0.59 & 0.24 & 0.093 & 0.43 & 0.57 & 0.008 & 1380 & 58140 \\
\hline Ogo2 & 5145 & 5164 & 6 & 4 & 0.66 & 0.19 & 0.11 & 0.24 & 0.76 & 0.15 & 243 & 21660 \\
\hline
\end{tabular}

Table 2: Summary of Petrophysical Parameters Obtained for Reservoir 2

\begin{tabular}{|c|c|c|c|c|c|c|c|c|c|c|c|c|}
\hline Wells & $\begin{array}{l}\text { Top } \\
\text { (m) }\end{array}$ & $\begin{array}{l}\text { Bottom } \\
\text { (m) }\end{array}$ & $\begin{array}{c}\text { Gross } \\
\text { Thickness } \\
(\mathrm{m})\end{array}$ & $\begin{array}{c}\text { Net } \\
\text { Thickness } \\
(\mathrm{m})\end{array}$ & $\begin{array}{l}\mathrm{N} / \mathrm{G} \\
(\%)\end{array}$ & $\begin{array}{c}\text { Porosity } \\
\varnothing \\
\text { (v/V) } \\
\end{array}$ & Swirr & $\begin{array}{c}\text { Water } \\
\text { Saturation } \\
\mathrm{S}_{\mathrm{w}} \\
\end{array}$ & $\mathrm{Sh}_{\mathrm{h}}$ & $V_{\text {sh }}$ & $\begin{array}{c}\mathrm{K} \\
(\mathrm{mD})\end{array}$ & $\begin{array}{c}\text { Vooip } \\
\left(\mathrm{m}^{3}\right)\end{array}$ \\
\hline Ogo1 & 1641 & 1649 & 8 & 5 & 0.63 & 0.29 & 0.08 & 0.89 & 0.11 & 0.02 & 5808 & 4338 \\
\hline Ogo2 & 1638 & 1644 & 6 & 4 & 0.66 & 0.09 & 0.24 & 0.14 & 0.86 & 0.17 & 3 & 7895 \\
\hline Ogo3 & 1647 & 1665 & 18 & 11 & 0.61 & 0.13 & 0.17 & 0.58 & 0.42 & 0.06 & 10.4 & 16708 \\
\hline
\end{tabular}

Table 3: Summary of Average Computed Petrophysical Parameters obtained for Reservoir 1-2

\begin{tabular}{|c|c|c|c|c|c|c|c|c|c|c|c|c|}
\hline Reservoir & $\begin{array}{l}\text { Top } \\
\text { (m) }\end{array}$ & $\begin{array}{l}\text { Bottom } \\
\text { (m) }\end{array}$ & $\begin{array}{c}\text { Gross } \\
\text { Thickness } \\
\text { (m) }\end{array}$ & $\begin{array}{c}\text { Net } \\
\text { Thickness } \\
\text { (m) }\end{array}$ & $\begin{array}{l}\mathrm{N} / \mathrm{G} \\
(\%)\end{array}$ & $\begin{array}{c}\text { Porosity } \\
\varnothing \\
\text { (v/V) }\end{array}$ & $S_{\text {wirr }}$ & $\begin{array}{c}\text { Water } \\
\text { Saturation } \\
S_{\mathrm{w}}\end{array}$ & $\mathrm{S}_{\mathrm{h}}$ & $\mathrm{V}_{\mathrm{sh}}$ & $\begin{array}{c}\mathrm{K} \\
(\mathrm{mD})\end{array}$ & $\begin{array}{l}\text { Vooip } \\
\left(\mathrm{m}^{3}\right)\end{array}$ \\
\hline Reservoir1 & 1563 & 1575 & 12 & 7 & 0.58 & 0.26 & 0.10 & 0.33 & 0.67 & 0.079 & 812 & 39900 \\
\hline Reservoir2 & 1642 & 1653 & 11 & 7 & 0.64 & 0.17 & 0.16 & 0.53 & 0.47 & 0.083 & 1940 & 9647 \\
\hline
\end{tabular}




\section{Ogo 1}

Ogo 2

Ogo 3

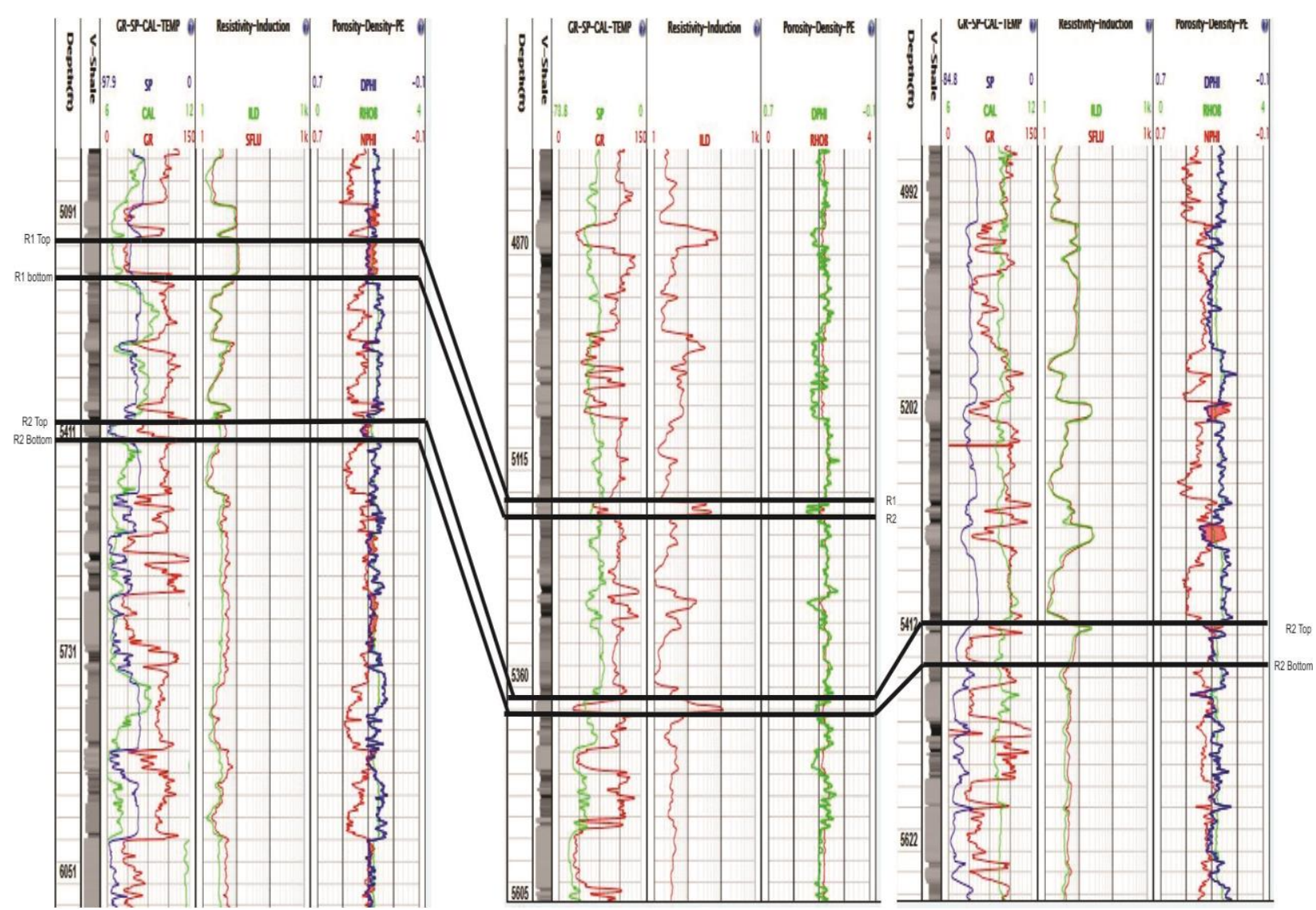

Fig 2: Well Correlation ofOgo1, Ogo2 and Ogo3 using: Gamma Ray, Resistivity, Density and Neutron logs respectively.

The prolific sand i.e. reservoirs R1 and R2 withvarying thickness were identified and mapped at depth of 1563 $\mathrm{m}$ and 1642 irrespectively. Across the wells reservoir 1 shows an average porosity of 0.26 and volume of shale 0.079 average hydrocarbon saturation is 0.67 . It average permeability of $812 \mathrm{md}$. The volume of oil in place for reservoir1 is $39900 \mathrm{~m}^{3}$. Reservoir 2shows an average porosity and volume of shale at 0.17 and 0.083 respectively. It has an average permeability of $1940 \mathrm{md}$. Ogo2 and Ogo3 have hydrocarbon saturation at 0.86 and 0.42 respectively. The volume of oil in place reservoir 2 is $9647 \mathrm{~m}^{3}$. Ogo 1 is not economically viable.

It is obvious that some of the sand in the wells correlate. This can be justified by the reservoir depth of Ogo 1 and 2 in reservoir 1 and Ogo1, 2 and 3 in reservoir 2. From all the petrophysical estimation and calculation of oil in place we can say that reservoir 1 is more economically viable than reservoir 2.

\subsection{Recommendation}

It is recommended that more well correlations should be carried out before embarking on drilling and well completion so as to save cost.

Proper well correlation will serve as a data bank for reference purposes to enhance the life span of the well.
This also gives more detailed information about the field for work over activity.

We are of the view that $4-\mathrm{D}$ seismic data acquisition be conducted with the view of revealing the current fluid movement with time.

Also vertical seismic profiles should be acquired in fields that have been left for long (especially areas that were acquired in 2-D in the 80's) to avoid drilling a dry well.

More advanced well $\log$ analysis tools and more advanced core data would help evaluate the reservoir in more detail. This could include special core analysis that would look at relative permeability, wettability, and capillary pressure. Nuclear magnetic resonance (NMR) logging tools would also be useful for getting information about formation fluids and porosity and better calibrating the saturation model.

\section{REFERENCES}

[1] Archie, G. E. The Electrical Resistivity as an Aid in Determining Some Reservoir Characteristics. J. Petrol. Technol. 5:54-62.

[2] Asquith, G. and Krygowski, D. Basic Well Log Analysis: AAPG Methods in Exploration Series. (16) 2004. 1942. 
[3] Dewan, J. T. Open-Hole Nuclear Logging - State of the Art - SPWLA Twenty-Seventh Annual Logging Symposium, Chicago, United States. June 9-13. 21-23. 1986.

[4] Doust, H. and Omatsola, E. Niger Delta. In: Divergent and Passive Basins (Eds. Edward, P. A. and Santogrossi, P. A.). The American Association of Petroleum Geologists, Tulsa, USA, 239-248. 1990.

[5] Dresser, A. Log Interpretation Charts (Houston, Texas, Dresser Industries Inc. p. 107). 1979.

[6] Ejedawe, J. E. Patterns of Incidence of Oil Reserves in Niger Delta Basin. American Association of Petroleum Geologists, 65: 1574-1585. 1981.

[7] Ejedawe J. E. The Eastern Niger Delta: geological evolution and hydrocarbon occurrences. SPDC Internal Report, Exploration Note 89. 002. 1989.

[8] Evamy, B. D., Haremboure, J., Kamerling, P., Knaap, W. A., Molloy, F. A. and Rowlands, P. H. Hydrocarbon Habitat of Tertiary Niger Delta. American Association of Petroleum Geologists Bulletin, 62(3): 277-298. 1978.

[9] Hearst, J. R., Nelson, P. H., Paillett, F. L. Well Logging for Physical Properties - A Handbook for Geophysicists, Geologists and Engineers. (2 ${ }^{\text {nd }}$ ed.). Wiley, 50. 2000.
[10] Kulke, H. Nigeria, Regional Petroleum Geology of the World. Part II: Africa, America, Australia and Antarctica. (Ed. Kulke, H), Berlin, Gebrüder Borntraeger, 8: 143-172. 1995.

[11] Oyedele, K. F., Oladele S., Ogagarue, D. O. and Bakare, K. Sequence Stratigraphic Approach to Hydrocarbon Exploration in Bobsaa Field, Onshore Niger Delta, Journal of Petroleum and Gas Exploration Research, 2(6): 106-114. 2012.

[12] Schlumberger Well Services Manual; Log Interpretation Principles, 1: 1-6. 2004.

[13] Sheriff, R. E. and Geldart, L. P. Exploration Seismology (2nd ed.). Cambridge University Press, 3491995.

[14] Tuttle, M. Charpentier, R. and Brownfield, M. "The Niger Delta Petroleum System: Niger Delta Province, Nigeria, Cameroon, and Equatorial Guinea, Africa". United States Geologic Survey. http://pubs.usgs.gov/. Retrieved 6 March 2015.

[15] Weber, K. J. Sedimentological aspects of oil fields in the Niger Delta. Geologeen Mijnbouw 50:559-576. 1972.

[16] Glover, P. Total Grammer Ray Log Petrophysics M.Sc. course note pp 10. 2015.

[17] Chigbata, N. C., Thesis submitted for Bachelor of Science, Benson Idahosa University. 2016. 